\title{
Model of Unique Material Flow in Context with Layout of Manufacturing Facilities
}

\author{
Martin Straka $^{1}$, Peter Kačmáry ${ }^{1}$, Andrea Rosová ${ }^{1}$, Boris Yakimovich ${ }^{2}$, Aleksander Korshunov ${ }^{2}$ \\ ${ }^{1}$ Institute of Logistics, Faculty of Mining, Ecology, Process Control and Geotechnology, Technical university of Kosice, \\ Park Komenskeho 14, 043 84, Kosice. Slovak Republic. E-mail: martin.straka@tuke.sk, peter.kacmary@tuke.sk, an- \\ drea.rosova@tuke.sk \\ ${ }^{2}$ Department of Higher Mathematics, Physics, Chemistry, Votkinsk Branch of Kalashnikov Izhevsk State Technical Uni- \\ versity, Studencheskaya 7, 426069 Izhevsk, Russia. E-mail: yakimovich@istu.ru, kai@istu.ru
}

The situation of analysis and finding solution of unique material flow managing and planning in production company allows increasing the competitiveness company on the market. The uniqueness of the material flows is in its combination of metallurgical and machinery character. There are continuous metallurgical and discrete mechanical material flow with even different speed which are joining at one place - aluminium casting. The research has brought also the recommendation of new layout of the company. Each company is original from the point of production processes. Application of standard enterprise information system (SAP, proAlpha, Baan, etc.) need difficult adaptation especially for conditions of small or medium enterprises and the price of that system is relatively high. Therefore, the proposed model of capacity planning is much more suitable for the conditions, requires and demands of this enterprisers.

Keywords: layout, material flow, manufacturing, production process

\section{Acknowledgement}

Publication has been created with the support of VEGA grant agency, in the framework of grant task VEGA 1/0216/13 „Methods and new approaches study to measurement, evaluation and diagnostic performance of business processes in the context of logistics management company".

\section{References}

[1] JOHNSON, J. C., WOOD, D. F. (1996). Contemporary logistics, sixth ed., Prentice Hall, Upper Saddle River.

[2] KHOURI, S., KAČMÁRY, P. (2009). Optimization of information flows in a model enterprise through the implementation of ERP system, Transport and Logistics Vol. 2009, No. 6, pp. 125-127.

[3] KOLLÁR, P., NIKITIN, Y., STRAKA, M. (2015). The determination of the shelf mass in the universal shelving stacker by measuring the frequency converter torque generating current of the main drive, Manufacturing technology, Vol. 15, No. 3, pp. 363-366.

[4] LASCSÁKOVÁ, M. (2015.). The analysis of the commodity price forecasting success considering different lengths of the initial condition drift, Acta Logistica, Vol. 2, No. 3, pp. 7-12.

[5] PEKARČÍKOVÁ, M., TREBUŇA, P., POPOVIČ, R., KLIMENT, M. (2015). Utilization of the software product Tecnomatix Jack in optimizing of working activities, Acta Simulatio, Vol. 1, No. 4, pp. 5-11.

[6] RAYWARD-SMITH, V. J., OSMAN, I. H., REEVES, C. R., SMITH, G. D. (1996). Modern heuristic search methods, UNICON John Wiley \& Sons, Chichester.

[7] RAZZHIVINA, M. A., YAKIMOVICH, B. A., KORSHUNOV, A. I. (2015). Application of information technologies and principles of lean production for efficiency improvement of machine building enterprises, Pollack Periodica, Vol. 10, Issue 2, pp. 17-23.

[8] ROSOVA, A. (2010). The system of indicators of distribution logistics, logistic of transport and material flow as one of the tools of controlling in the enterprise logistics, Acta Montanistica Slovaca, Vol. 2010, No. 1, pp. 67-72.

[9] SANIUK, S., SANIUK, A., LENORT, R., SAMOLEJOVA, A. (2014). Formation and planning of virtual production networks in metallurgical clusters, Metalurgija, Vol. 53, No. 4, pp. 725-727.

[10] SĄSIADEK, M. (2015). Planning and analysis of mechanical assembly sequences in design engineering - part I: the method, Tehnički Vjestnik, Technical Gazette, Vol. 22, No. 2, pp. 337-342.

[11] SĄSIADEK, M. (2015). Planning and analysis of mechanical assembly sequences in design engineering - part II: application, Tehnički Vjestnik, Technical Gazette, Vol. 22, No. 3, pp. 643-648.

[12] STRAKA, M. (2011). Analysis and the conception proposal of manufacturing facilities layout, Carpathian Logistics Congress CLC'2011, TU of Kosice, pp. 1-4. 
[13] STRAKA, M., ŽATKOVIČ, E., SCHRÉTER, R. (2014). Simulation as a means of activity streamlining of continuously and discrete production in specific enterprise, Acta Logistica, Vol. 1, No. 3, pp. 11-16.

[14] SZABO, S., FERENC, V., PUCHAR, A. (2013). Trust, Innovation and Prosperity, Quality Innovation Prosperity, Vol. 17, No. 2, pp. 1-8.

[15] PELAGRIĆ, Z., NÁGEL, M., ŽMINDÁK, M., RIECKY, D. (2015). Wear simulation modeling by using the finite element method, Manufacturing technology, Vol. 15, No. 2, pp. 191-195.

[16] BEZECNÝ, J., DUBEC, A., JANEKOVÁ, M. (2015). Brazing operation for aluminium semi-products by heat treatment, Manufacturing technology, Vol. 15, No. 1, pp. 3-7.

[17] PRAJOVÁ, V., PERMINOVA, O., FAIZULLIN, R. (2014). Principles of organizations interaction while forming mechatronics specialists professional competences in a regional industry cluster. Procedia Engineering: The 6th International Conference on Modelling of Mechanical and Mechatronic Systems MMaMS 2014, Vol. 96, online, pp. 370-373.

[18] BOŽEK, P., MORAVČÍK, O., ŠTOLLMANN, V., ŠURIANSKY, J., PRAJOVÁ, V., WALEKOVÁ, G. (2008). Virtual program imported into the real technological workplace. Vienna: Annals of DAAAM and Proceedings of DAAAM Symposium, pp. 0157-0158. 